\title{
Germination Characteristics and Mobilization of Seed Reserves in Maize Varieties as Influenced by Temperature Regimes
}

\author{
S. SIKDER ${ }^{1 *}$, M. A. HASAN ${ }^{2}$ \& M. S. HOSSAIN ${ }^{3}$ \\ ${ }^{1,2 \& 3}$ Department of Crop Physiology and Ecology, Hajee Mohammad Danesh Science \& \\ Technology University, Dinajpur-5200, Bangladesh
}

\begin{abstract}
In a laboratory experiment seeds of four maize varieties viz., BARI hybrid maize -5, BARI hybrid maize -2, BARI maize -7 and BARI maize -5 were germinated at 24,30 and $36^{\circ} \mathrm{C}$ to study seed metabolic activity and seed reserve translocation. Temperature had significant effect on germination characteristics and seed reserves mobilization. The shoot dry weights were increased with the increase of temperature from 24 to $36^{\circ} \mathrm{C}$. But in root dry weight and length of shoot and root the highest value was found at $30^{\circ} \mathrm{C}$ compared to 24 to $36^{\circ} \mathrm{C}$. At moderate temperature $\left(30^{\circ} \mathrm{C}\right)$ all the varieties showed highest seed metabolic efficiency (SME) than those of at 24 and $36^{\circ} \mathrm{C}$ temperature and hybrid varieties BARI hybrid maize -2 and BARI hybrid maize -5 attained higher seed metabolic efficiency than the BARI maize -5 and BARI maize -7 .
\end{abstract}

Key words: Maize; temperature; germination; seed metabolic efficiency.

\section{INTRODUCTION}

Maize (Zea mays L.) is the only member of the genus Zea of tribe maydeae under the family gramineae. It is a $\mathrm{C}_{4}$ plant and has high production potential for high photosynthetic capacity (Goldsworthy, 1984). Maize uses nutrients more efficiently due to its deep rooting system and it is more tolerant to drought than rice and wheat.

Seed germination and seedling establishment are important characters for maize production. This may be dependent on their ability to utilize seed reserves more efficiently (Rao and Sinha, 1993). Germination and mobilization of seed reserves may vary in different temperature regimes (Penning de Vries et al., 1979) because temperature is a modifying factor in germination since it can influence the rate of water and other substrates supply necessary for growth and development (Wanjura and Buxtor, 1972). The magnitude of variation in mobilization of seed reserves may also vary in different genotypes and higher seed metabolic efficiency (SME) is a desirable character under water stress environment when emergence is delayed due to insufficient soil moisture. Genotypes with high SME would not run out the substrates before germination. However, the present work was undertaken to study the mobilization of seed reserves and evaluate the seed metabolic efficiency of maize varieties as influenced by temperature during germination.

\footnotetext{
* Corresponding author: Associate Professor, Department of Crop Physiology and Ecology, Hajee Mohammad Danesh Science \& Technology University, Dinajpur-5200, E-mail: srisikder@gmail.com

(C) 2009 School of Agriculture and Rural Development, Bangladesh Open University, All rights reserved.
} 


\section{S. Sikder et al.}

\section{Materials And Methods}

The experiment was conducted at Laboratory of Crop Physiology and Ecology Department, Hajee Mohammad Danesh Science and Technology University, Dinajpur, during March-April, 2008. The experiment was carried out in two factors completely randomized design with three replications. The treatment factors $A$ and $B$ were as follows-

A. Three levels of germination temperature: 24,30 and $36^{\circ} \mathrm{C}$.

B. Four maize varieties : BARI Maize -5, BARI maize -7, BARI Hybrid maize -2 and BARI Hybrid maize -5 . The seeds of varieties were collected from Genetic Resource Unit of Bangladesh Agricultural Research Institute (BARI) Joydebpur, Gazipur.

Seed placement for germination: Before placement of seed for germination, seeds were mixed thoroughly and the moisture percentage was determined gravimetrically using a portion of the seeds. The remaining seeds were used for the experiment. Individual weight of 20 seeds for each variety was taken and placed sequentially with marking on filter paper soaked with water in sterilized Petri dishes. Then the petri dishes were kept in seed germinator at 24,30 and $36^{\circ} \mathrm{C}$. For each temperature three batches of petri dishes each containing 20 seeds were used. Water was added to the petri dishes as and when necessary.

Rate of germination, co-efficient of germination and vigor index were measured at 24-hour interval and continued up to $5^{\text {th }}$ day $(120 \mathrm{~h})$. A seed was considered to be germinated when radicle and plumule came out with more than $2 \mathrm{~mm}$ long.

The rate of germination was calculated following Krishnasamy and Seshu (1990), as-

Rate of germination $(\%)=\frac{\text { No. of seed germinated at } 48 \mathrm{~h}}{\text { No. of seed germinated at } 120 \mathrm{~h}} \times 100$

Co-efficient of germination and vigor index were calculated using the following formulae (Copeland, 1976).

Co-efficient of germination $=\frac{100\left(A_{1}+A_{2}+-----+A_{n}\right)}{A_{1} T_{1}+A_{2} T_{2}+---+A_{n} T_{n}}$

Vigor index $=\frac{A_{1}}{T_{1}}+\frac{A_{2}}{T_{2}}+------+\frac{A_{n}}{T_{n}}$

Where, $A=$ Number of seeds germinated

$\mathrm{T}=$ Time (days) corresponding to $\mathrm{A}$

and $n=$ No. of days to final count

Shoot and root length and dry matter partitioning: At $5^{\text {th }}$ day after placement for germination, five seedlings from each petri dish were sampled. Shoot and root length of individual seedling were recorded manually with scale. Then shoot, root and remaining seeds were dried separately at $70^{\circ} \mathrm{C}$ for $72 \mathrm{~h}$ and the weights were recorded. The mean length $(\mathrm{cm})$ and dry weight were calculated for each treatment combination.

Seed metabolic efficiency: Seed metabolic efficiency may be defined as the amount of shoot and root dry matter ( $\mathrm{g}$ ) produced form 1 unit $(\mathrm{g})$ of dry seed weight that was respired. Thus higher the value of seed metabolic efficiency (SME), the higher is the efficiency of seed as more seed reserves would be used for producing roots and shoots.

Amount of seed material respired (SMR) was calculated as -

SMR $=$ SDW-(SHW+RTW+RSW)

Where, SDW= Seed dry weight before germination

SHW= Shoot dry weight

RTW= Root dry weight

$\mathrm{RSW}=$ Remaining seed dry weight 
Seed metabolic efficiency (SME) was calculated using the following formula (Rao and Sinha, 1993)

$$
\mathrm{SME}=\frac{\mathrm{SHW}+\mathrm{RTW}}{\mathrm{SMR}}
$$

Statistical analysis: The findings were analyzed by partitioning the total variance with the help of computer using MSTAT program. The treatment means were compared using Duncan's Multiple Range test (DMRT).

\section{Results AND Discussion}

\section{Germination characteristics}

Results showed that the rate of germination was significantly influenced by the interaction effect of temperature regimes and maize varieties (Table 1). Co-efficient of germination and germination vigor index of the varieties were also influenced significantly by the combined effect of temperature regimes and varieties. But at $24^{\circ} \mathrm{C}$ temperature, the rate of' germination was the lowest $(65.00-$ $73.72 \%)$. At $30^{\circ} \mathrm{C}$, all the maize varieties showed the highest rate of germination (73.29-77.59\%). The highest germination rate was found in BARI hybrid maize $-5(77.59 \%)$ at $30^{\circ} \mathrm{C}$ which was statistically similar to all other varieties. At $36^{\circ} \mathrm{C}$ the germination rate was decreased compared to $30^{\circ} \mathrm{C}$ except BARI maize -7 (75.59\%).

Table 1. Rate of germination (\%), Co-efficient of germination (\%) and Germination vigor index in four maize varieties as influenced by temperature regimes

\begin{tabular}{lcccc}
\hline \multicolumn{1}{c}{ Maize varieties } & $\begin{array}{c}\text { Temperatures } \\
\left({ }^{\circ} \mathrm{C}\right)\end{array}$ & $\begin{array}{c}\text { Rate of } \\
\text { germination }(\%)\end{array}$ & $\begin{array}{c}\text { Co-efficient of } \\
\text { germination (\%) }\end{array}$ & $\begin{array}{c}\text { Germination } \\
\text { vigor index }\end{array}$ \\
\hline \multirow{3}{*}{ BARI hybrid maize -5} & 24 & $65.00 \mathrm{~d}$ & $27.22 \mathrm{ab}$ & $20.69 \mathrm{ab}$ \\
& 30 & $77.59 \mathrm{a}$ & $27.70 \mathrm{a}$ & $21.66 \mathrm{a}$ \\
& 36 & $68.00 \mathrm{~cd}$ & $27.34 \mathrm{ab}$ & $18.73 \mathrm{~b}$ \\
BARI hybrid maize -2 & 24 & $71.21 \mathrm{bc}$ & $26.83 \mathrm{~b}$ & $20.91 \mathrm{ab}$ \\
& 30 & $74.12 \mathrm{ab}$ & $27.60 \mathrm{ab}$ & $21.44 \mathrm{ab}$ \\
& 36 & $73.76 \mathrm{ab}$ & $27.62 \mathrm{ab}$ & $20.81 \mathrm{ab}$ \\
BARI maize -7 & 24 & $73.72 \mathrm{ab}$ & $27.62 \mathrm{ab}$ & $21.04 \mathrm{ab}$ \\
& 30 & $73.29 \mathrm{ab}$ & $27.59 \mathrm{ab}$ & $22.80 \mathrm{ab}$ \\
BARI maize -5 & 36 & $75.59 \mathrm{ab}$ & $27.70 \mathrm{a}$ & $19.78 \mathrm{ab}$ \\
& 24 & $71.31 \mathrm{bc}$ & $27.51 \mathrm{ab}$ & $21.46 \mathrm{ab}$ \\
CV (\%) & 30 & $74.55 \mathrm{ab}$ & $27.62 \mathrm{ab}$ & $19.96 \mathrm{ab}$ \\
\hline
\end{tabular}

In a column, means followed by the same letter(s) do not differ significantly at $5 \%$ level as per DMRT.

Co-efficient of germination was increased with increasing temperature. The lowest value (26.83\%) was found at $24^{\circ} \mathrm{C}$ in BARI hybrid maize -2 at $5^{\text {th }}$ day, which was statistically similar to all other maize varieties at $24^{\circ} \mathrm{C}$. The highest value $(27.70 \%)$ was found in BARI maize -7 at $36^{\circ} \mathrm{C}$ which was statistically similar to all other varieties at $36^{\circ} \mathrm{C}$. At $30^{\circ} \mathrm{C}$ all the varieties showed the coefficient of germination ranges from 27.59-27.70\%.

Germination vigor indices showed an increasing trend with increasing temperature from 24 to $30^{\circ} \mathrm{C}$. At $24^{\circ} \mathrm{C}$, the indices ranged from 20.69 to 21.46 , which were increased to the highest level (21.44 to 22.80 ) at $30^{\circ} \mathrm{C}$ except BARI maize $-5(19.96)$. At $36^{\circ} \mathrm{C}$, in all maize varieties, the germination vigor indices decreased compared to $30^{\circ} \mathrm{C}$.

Faster speed of germination at higher temperature might be due to rapid hydrolysis and mobilization of seed reserves through higher alpha amylase activity at higher temperature. The close relation between germination of wheat seed and alpha amylase activity at various 


\section{S. Sikder et al.}

temperatures was reported by Sultana el al. (2000). In respect of speed of germination all maize varieties behaved almost similar at different temperature and similar result was found by Sikder et al. (2004).

\section{Length of seedling}

The length of shoot and root of maize seedling was influenced significantly by the interaction effect of temperature and maize varieties (Table 2). The shoot length was the lowest in BARI maize -5 $(2.43 \mathrm{~cm})$ which was statistically comparable to all other varieties at $24^{\circ} \mathrm{C}$. Shoot length increased $(6.42$ to $9.30 \mathrm{~cm})$ at $30^{\circ} \mathrm{C}$ which was considered to be optimum temperature for maize seedling growth. BARI hybrid maize -2 showed the highest shoot length at $30^{\circ} \mathrm{C}$. At $36^{\circ} \mathrm{C}$ temperature, shoot length decreased in all maize varieties as compared to $30^{\circ} \mathrm{C}$.

Table 2. Length of shoot and root of maize seedlings as influenced by temperature regimes

\begin{tabular}{ccccc}
\hline \multirow{2}{*}{ Maize varieties } & $\begin{array}{c}\text { Temperatures } \\
\text { M }\end{array}$ & \multicolumn{3}{c}{ Length (cm/seedling) } \\
\cline { 3 - 5 } & 24 & shoot & root & shoot : root \\
\hline \multirow{3}{*}{ BARI hybrid maize -5} & 30 & $3.94 \mathrm{~g}$ & $10.20 \mathrm{~g}$ & $0.38 \mathrm{f}$ \\
& 36 & $8.90 \mathrm{~b}$ & $16.00 \mathrm{~b}$ & $0.56 \mathrm{~cd}$ \\
& 24 & $8.49 \mathrm{c}$ & $12.62 \mathrm{~d}$ & $0.67 \mathrm{~b}$ \\
BARI hybrid maize -2 & 30 & $5.26 \mathrm{f}$ & $10.50 \mathrm{fg}$ & $0.50 \mathrm{de}$ \\
& 36 & $9.30 \mathrm{a}$ & $17.30 \mathrm{a}$ & $0.54 \mathrm{~cd}$ \\
BARI maize -7 & 24 & $8.57 \mathrm{bc}$ & $11.67 \mathrm{e}$ & $0.73 \mathrm{a}$ \\
& 30 & $3.84 \mathrm{~g}$ & $8.4 \mathrm{i}$ & $0.45 \mathrm{e}$ \\
BARI maize -5 & 36 & $8.10 \mathrm{~d}$ & $13.56 \mathrm{c}$ & $0.59 \mathrm{c}$ \\
& 24 & $6.31 \mathrm{e}$ & $10.80 \mathrm{f}$ & $0.58 \mathrm{c}$ \\
& 30 & $2.43 \mathrm{~h}$ & $7.80 \mathrm{j}$ & $0.31 \mathrm{~g}$ \\
CV (\%) & 36 & $6.42 \mathrm{e}$ & $12.58 \mathrm{~d}$ & $0.51 \mathrm{~d}$ \\
& & $5.47 \mathrm{f}$ & $9.50 \mathrm{~h}$ & $0.57 \mathrm{c}$ \\
\hline
\end{tabular}

In a column, means followed by the same letter(s) do not differ significantly at $5 \%$ level as per DMRT.

In case of root length, the lowest value was attained at $24^{\circ} \mathrm{C}$. It increased at $30^{\circ} \mathrm{C}$ and thereafter decreased at $36^{\circ} \mathrm{C}$ in all maize varieties. At $36^{\circ} \mathrm{C}$, the reduction in root length from that at $30^{\circ} \mathrm{C}$ was lower $(2.76$ to $5.63 \mathrm{~cm})$ in all the varieties. The adverse effect of higher temperature $\left(36^{\circ} \mathrm{C}\right)$ on root length was more clearly noted than that of shoot length.

The shoot to root ratio of length increased with increasing temperature regimes in all maize varieties. It was low at $24^{\circ} \mathrm{C}(0.31$ to 0.50$)$, moderate at $30^{\circ} \mathrm{C}(0.51$ to 0.59$)$ and the highest at $36^{\circ} \mathrm{C}$ (0.57 to 0.73 ). The increasing shoot to root ratio of length with temperature regimes indicated that root was more affected than shoot at high temperature. These findings were supported by Hasan et al. (2004).

\section{Dry matter of seedling}

Result showed that the dry weight of shoot and root of maize seedlings was influenced significantly by the interaction effect of temperature regimes and maize varieties (Table 3). Generally shoot dry weight was increased with increasing temperature in all maize varieties. There exists significant variation in shoot dry weight at different temperature regimes among maize varieties. At $24^{\circ} \mathrm{C}$, the shoot dry weights were lower $(6.5$ to $15.6 \mathrm{mg} / \mathrm{seedling})$ than those of $30^{\circ} \mathrm{C}$ and $36^{\circ} \mathrm{C}$ (12.73 to $38.0 \mathrm{mg} /$ seedling). Variety BARI maize -5 had the lowest shoot dry weight (6.5 $\mathrm{mg} / \mathrm{seedling}$ ) and the variety BARI hybrid maize -2 had the highest shoot dry weight (15.6 $\mathrm{mg} /$ seedling) at $24^{\circ} \mathrm{C}$.

In case of root dry weight, the highest value was found at $30^{\circ} \mathrm{C}$ compared to $24^{\circ} \mathrm{C}$ and $36^{\circ} \mathrm{C}$ temperature. In all the varieties, it was reduced significantly both at $24^{\circ} \mathrm{C}$ and $36^{\circ} \mathrm{C}$ temperature (Table 3). The lowest root dry weight $(5.33 \mathrm{mg} / \mathrm{seedling})$ was obtained by variety BARI maize -5 at $24^{\circ} \mathrm{C}$ and the highest by variety BARI hybrid maize $-2(9.00 \mathrm{mg} / \mathrm{seedling})$ at $30^{\circ} \mathrm{C}$ temperature. 
Table 3. Dry weight of shoot and root of maize seedlings as influenced by temperature regimes

\begin{tabular}{ccccc}
\hline \multirow{2}{*}{ Maize varieties } & Temperatures & \multicolumn{3}{c}{ Dry weight (mg/seedling) } \\
\cline { 3 - 5 }$\left({ }^{\circ} \mathrm{C}\right)$ & shoot & root & shoot : root \\
\hline \multirow{2}{*}{ BARI hybrid maize -5} & 24 & $10.00 \mathrm{i}$ & $6.00 \mathrm{e}$ & $1.67 \mathrm{e}$ \\
& 30 & $27.33 \mathrm{e}$ & $7.33 \mathrm{c}$ & $3.73 \mathrm{~b}$ \\
& 36 & $28.00 \mathrm{de}$ & $7.30 \mathrm{c}$ & $3.83 \mathrm{~b}$ \\
BARI hybrid maize -2 & 24 & $15.60 \mathrm{~g}$ & $8.66 \mathrm{a}$ & $1.80 \mathrm{de}$ \\
& 30 & $38.00 \mathrm{a}$ & $9.00 \mathrm{a}$ & $4.22 \mathrm{a}$ \\
& 36 & $30.00 \mathrm{~b}$ & $7.33 \mathrm{c}$ & $4.09 \mathrm{a}$ \\
BARI maize -7 & 24 & $10.00 \mathrm{i}$ & $6.00 \mathrm{e}$ & $1.67 \mathrm{e}$ \\
& 30 & $28.66 \mathrm{~cd}$ & $7.80 \mathrm{~b}$ & $3.67 \mathrm{~b}$ \\
BARI maize -5 & 36 & $29.33 \mathrm{bc}$ & $7.20 \mathrm{c}$ & $4.08 \mathrm{a}$ \\
& 24 & $6.50 \mathrm{j}$ & $5.33 \mathrm{f}$ & $1.22 \mathrm{f}$ \\
CV (\%) & 30 & $12.73 \mathrm{~h}$ & $6.66 \mathrm{~d}$ & $1.91 \mathrm{~d}$ \\
\hline
\end{tabular}

In a column, means followed by the same letter(s) do not differ significantly at $5 \%$ level as per DMRT.

The shoot to root dry weight ratio was increased with increasing temperature in all varieties. Increment of ratio of shoot to root dry weight with increasing temperature indicated that root dry weight was reduced but shoot dry weight was increased at high temperature. BARI maize -5 had the lowest shoot to root dry weight ratio $(1.22)$ at $24^{\circ} \mathrm{C}$ where as variety BARI hybrid maize -2 obtained the highest value (4.22) of shoot to root dry weight ratio at $30^{\circ} \mathrm{C}$ temperature, but it decreased at $36^{\circ} \mathrm{C}$ (4.09).

Results from other studies like Sikder et al. (2004) and Hasan et al. (2004) in wheat varieties, it was found that shoot dry weight was increased significantly with increase in temperature. They also found that the shoot to root dry weight ratio was increased with the increasing temperature in different wheat varieties. All these findings support the results of present experiment.

\section{Seed metabolic efficiency (SME)}

Temperature had a profound effect on seed metabolic efficiency (SME) in all maize varieties (Table 4). At $30^{\circ} \mathrm{C}$ temperature, the SME was significantly higher than those at $24^{\circ} \mathrm{C}$ and $36^{\circ} \mathrm{C}$ in all the maize varieties. BARI hybrid maize -2 and BARI hybrid maize -5 showed higher SME $(0.55$ to 0.60 $\mathrm{g} / \mathrm{g})$ than other varieties $(0.28$ to $0.54 \mathrm{~g} / \mathrm{g})$ at $30^{\circ} \mathrm{C}$. At $24^{\circ} \mathrm{C}$ the highest SME value was found in BARI hybrid maize-5 $(0.43 \mathrm{~g} / \mathrm{g})$ and the lowest in BARI maize-5 $(0.26 \mathrm{~g} / \mathrm{g})$. At $36^{\circ} \mathrm{C}$, the highest SME value was found in BARI hybrid maize $-5(0.55 \mathrm{~g} / \mathrm{g})$ and the lowest in BARI maize $-5(0.28$ $\mathrm{g} / \mathrm{g}$ ) Sikder et al. (2004) found the highest SME in wheat at moderate temperature than those of lowest and highest temperature.

Table 4. Seed metabolic efficiency of four maize varieties as influenced by temperature regimes

\begin{tabular}{lcc}
\hline Maize varieties & Temperatures $\left({ }^{\circ} \mathrm{C}\right)$ & Seed metabolic efficiency \\
\hline \multirow{2}{*}{ BARI hybrid maize -5} & 24 & $0.43 \mathrm{~d}$ \\
& 30 & $0.60 \mathrm{a}$ \\
& 36 & $0.55 \mathrm{~b}$ \\
BARI hybrid maize -2 & 24 & $0.40 \mathrm{e}$ \\
& 30 & $0.55 \mathrm{~b}$ \\
BARI maize -7 & 36 & $0.39 \mathrm{e}$ \\
& 24 & $0.30 \mathrm{f}$ \\
BARI maize -5 & 30 & $0.54 \mathrm{~b}$ \\
& 36 & $0.48 \mathrm{c}$ \\
CV (\%) & 24 & $0.26 \mathrm{~h}$ \\
& 30 & $0.28 \mathrm{gh}$ \\
\end{tabular}

In a column, means followed by the same letter(s) do not differ significantly at $5 \%$ level as per DMRT. 


\section{S. Sikder et al.}

The highest $\mathrm{SME}$ at $30^{\circ} \mathrm{C}$ temperature suggested that at moderate temperature the respiratory loss was minimum and the respiratory product was efficiently used to produce new growth (shoot and root). But at high temperature $\left(36^{\circ} \mathrm{C}\right)$, reduction of SME could be due to increased rate of respiration but the respiratory product some how failed to accumulate respiratory product to shoot and root of maize seedlings. In lowest SME at $24^{\circ} \mathrm{C}$ suggested that at lower temperature, respiration was not linked to build useful plant parts and could led to thermal dissipation of respiratory energy by an alternate oxidase pathway or cyanide resistant pathway as suggested by Henry and Nyns (1975).

\section{Conclusion And Recommendation}

From the overall results it might be concluded that the BARI hybrid maize -2 and BARI hybrid maize -5 varieties showed better performance in mobilization of seed reserves compared to the rest of the varieties. Finally, two hybrid varieties had the highest SME at all the temperatures which is a desirable character under hot and water stress environment when emergence is delayed due to insufficient soil moisture. These varieties would not run out of substrate before emergence. It would be desirable to screen the genotypes having high SME for inclusion in the breeding programme.

\section{LiterATURE CITED}

Goldsworthy, P. R. 1984. Crop growth \& development: the reproductive- phase. In "Physiology of Tropical Field Crop" (P. R. Goldsworthy and N. M. Fisher, Eds.), John Willey \& Sons. pp. 163212.

Rao, D. G. and Sinha, S. K. 1993. Efficiency of mobilization of seed reserves in sorghum hybrids and their parents as influenced by temperature regimes. Seed Research. 2(2), 97-100.

Penning de Vries, F. W. T., Witlage, J. M. and Kremer, D. 1979. Rate of respiration and increase in structural dry matter in young wheat, ryegrass and maize plants in relation to temperature, to water stress and to their sugar content. Ann Bot 44, 595-609.

Wanjura, D. F. and Buxtor, D. R. 1972. Hypocotyl and radicle elongation of cotton as affected by soil environment. Agron J 64, 431-435.

Krishnasamy, V. and Seshu, D. V. 1990. Germination after accelerated aging and associated characters in rice varieties. Seed Sc and Tech 18, 353-359.

Copeland, L. O. 1976. Principles of seed science and technology. Burgess Pub. Com., Minneapolis, Minnesota. pp. 164-165.

Sultana, N., Ikeda, T. and Mitsui, T. 2000. $\mathrm{GA}_{3}$ and proline promote germination of wheat seeds by stimulating alpha-amylase at unfavorable temperatures. Plant Prod Sci 3(3), 232-237.

Sikder, S., Ahmed, J. U., Haque, M. M., Hasan, M. A. and Bahadur, M. M. 2004. Mobilization of seed reserves in wheat varieties as influenced by temperature regimes. J Sci Tech 2, 29-33.

Hasan, M. A., Ahmed, J. U., Hossain, T., Hossain, M. M. and Ullah M. A. 2004. Germination characters and seed reserve mobilization during germination of different wheat genotypes under variable temperature regimes. J Natn Sci Found Srilanka 32(3\&4), 97-107.

Henry, M. P. and Nyns, E. J. 1975. Cyanide insensitive respiration. An alternative mitochondrial pathway. Sub cell Biochem 4, 1-65. 